\title{
Penerapan ICT dalam Pelayanan Publik di Kabupaten Bantul
}

\author{
Supardal*) \\ Program Studi Ilmu Pemerintahan, Sekolah Tinggi Pembangunan Masyarakat Desa "APMD", \\ Jl. Timoho, Baciro, Gondokusuman, Kota Yogyakarta, Daerah Istimewa Yogyakarta, Indonesia \\ Diterima : 11 Agustus 2016; Disetujui : 28 September 2016; Dipublikasikan 14 Oktober 2016
}

\begin{abstract}
The transformation of the bureaucracy into a necessity. One way transformation of the bureaucracy in the public service is the application of information and communications technology (ICT) in the public service. Information Communication Technology innitiative and application in local government should transform local government bureaucracy in public service. In Bantul, however, ICT innitiative and application has not successfully transformed local government bureaucracy in public service. This study will assessed on the impact of ICT innitiative and application on the bureaucracy transformation in public service. The mix research method is choosen in order to answer and analysis the phenomena in depht. The research found that the influence of the ICT's innitiative on the bureaucracy transformation in the Bantul District is only $18 \%$. The low effect of the implementation of the system of ICT in those cities is affected by strong patronage culture, the hierarchical organizational structure and centralized regulation on local government structure, low capacity eleadership of middle range leader, and no delegation from top leader to middle management.
\end{abstract}

Keywords: public service; bureaucracy; transformation; culture; ICT

\begin{abstract}
Abstrak
Transformasi birokrasi menjadi keharusan. Salah satu cara transformasi birokrasi dalam pelayanan publik adalah penerapan teknologi informasi dan komunikasi (ICT) dalam pelayanan publik. Praksarsa dan implementasi Teknologi Informasi Komunikasi di pemerintah daerah harus mengubah birokrasi pemerintah daerah dalam pelayanan publik. Di Bantul, bagaimanapun, Praksarsa dan Implementasi ICT belum berhasil mengubah birokrasi pemerintah daerah dalam pelayanan publik. Penelitian ini akan dinilai pada dampak Prakarsa dan Implementasi ICT pada transformasi birokrasi dalam pelayanan publik. Metode penelitian campuran yang terpilih untuk menjawab dan analisis fenomena. Penelitian ini menemukan bahwa pengaruh Prakarsa ICT pada transformasi birokrasi di Kabupaten Bantul hanya 18\%. Pengaruh rendah dari pelaksanaan sistem ICT di kotakota dipengaruhi oleh budaya yang Patronase yang kuat, struktur organisasi hirarkis dan regulasi terpusat pada struktur pemerintah daerah, kapasitas rendah e-kepemimpinan middle leader, dan tidak ada delegasi dari top leader ke middle management.
\end{abstract}

Kata kunci : pelayanan publik; birokrasi; transformasi; budaya; ICT

Cara Penulisan Sitasi : Supardal, S. (2016). Penerapan ICT dalam Pelayanan Publik di Kabupaten Bantul. Otoritas : Jurnal Ilmu Pemerintahan, 6(2), 120-134.

*)Penulis Korespondensi.

E-Mail : gusdal66@gmail.com

Copyright (C) 2016, Otoritas : Jurnal Ilmu Pemerintahan, p-ISSN: 2088-3706, e-ISSN: 2502-9320 
Tersedia Online di http://journal.unismuh.ac.id/index.php/otoritas

Otoritas : Jurnal Ilmu Pemerintahan, 6 (2), Oktober 2016, 121

\section{Pendahuluan}

Dalam perspektif teori kelembagaaan (Scott, 2001), struktur organisasi untuk mendorong transformasi kelembagaan yang dipengaruhi ICT dilihat dari pilar. Bila kita melihat pelaksanaan sistem ICT di Kabupaten Bantul sejak tahun 2005, juga belum menunjukkan kapasitas birokrasi yang memadai dalam memberikan respon aspirasi warganya. Untuk itu di Kabupaten Bantul menurut Kepala Kantor Pengolahan Data Telematika menuturkan bahwa : setiap tahun diselenggarakan penguatan kapasitas aparat Pemerintah Kabupaten Bantul untuk meningkatkan kemampuan aparat dalam bidang ICT. ICT yang dimaknai sebagai system enabled process transformation, social innovation and digital inclusion in the public sector (Weerakkody dkk., 2011).

Karena tantangan terbesar dalam pelaksanaan sistem ICT di Kabupaten Bantul adalah rendahnya kapasitas aparat dalam mengoperasionalkan perangkat ICT. Hal ini menunjukkan bahwa sebagian besar aparat pemda belum mempunyai kapasitas memadai dalam bidang ICT, atau dengan kata lain pelaksanaan sistem ICT belum mampu mendorong transformasi birokrasi daerah.

Ada beberapa kajian Penelitian soal penerapan E-Government dan ICT secara khusus dalam pemerintahan, seperti yang diteliti oleh Mustapa (2011) mengenai peluang dan tantangan dalam pelayanan publik terkait dengan penerapan EGovernment sebagai bagian dari reformasi publik. Selain itu adapula penelitian yang dilaksanakan oleh Sosiawan (2015) yang meneliti tentang Tantangan dan Hambatan dalam implementasi EGovernment di Indonesia yang dinilai memiliki ancaman berat. Penelitian Habibullah (2010) juga menambah wawasan kita terkait pemanfaatan dan pengembangan E-Government.

Dalam kajian ini mengambil celah riset (research gap) tentang kapasitas respon birokrasi dalam menerima aspirasi warga, karena belum banyak dilakukan oleh para peneliti sebelumnya, khususnya penerapan sistem ICT dan pengaruhnya terhadap transformasi birokrasi. Dalam penelitian ini menggunakan studi penerapan ICT khususnya kasus E-government , khususnya SMS Center atau sistem online diskusi warga Kabupaten Bantul. Kebijakan e-government di Kabupaten Bantul tahun 2005. Sejauhmana pelaksanaan ICT mampu mempengaruhi transformasi birokrasi di Kabupaten Bantul?

\section{Metode Penelitian}

Dalam penelitian ini dipergunakan jenis penelitian mixed method atau metode campuran yakni teknik analisis kuantitatif dan kualitatif. Dimulai dengan uji statistis untuk mengetahui hubungan pengaruh antar variabel. Selanjutnya hasilnya dianalisis secara kualitatif untuk membuktikan dan memberikan argumentasi yang mendukung hasil tersebut, berdasarkan wawancara mendalam dengan pejabat struktural.

Objek penelitian adalah pelaksanaan ICT dan pengaruhnya terhadap pelayanan publik di Kabupaten Bantul. Subjek penelitian adalah pejabat struktural di lingkungan pemda Bantul. Untuk informan dan responden yang dijadikan narasumber berdasarkan population sampling sebesar 80 orang untuk Kabupaten Bantul.

Observasi dilakukan untuk mengamati berbagai praktek pelayanan publik berbasis ICT di masing-masing pemerintahan daerah, dan juga kapasitas pegawai untuk melaksanakan pelayanan berbasis ICT. Kuesioner digunakan untuk mengetahui pendapat responden dari unsur pejabat struktural di lingkungan pemerintah daerah berkaitan dengan pelaksanaan ICT dan pengaruhnya terhadap pelayanan publik.

Wawancara yang Mendalam dipergunakan dengan fungsi untuk dapat 
Tersedia Online di http://journal.unismuh.ac.id/index.php/otoritas

Otoritas : Jurnal Ilmu Pemerintahan, 6 (2), Oktober 2016, 122

memperoleh wawasan dan perspektif informan terkait dengan pelaksanaan ICT dan perannya dalam mendorong percepatan pelayanan publik. Dilakukan dengan para pejabat struktural yang memahami konteks kebijakan ICT dan penggunaannya.

Analisis data dilakukan dengan analisis campuran (mixed method) antara kuantitatif dan kualitatif, dimana dilakukan analisis kuantitatif dengan SPSS, selanjutnya dilakukan analisis kualitatif untuk menjelaskan fenomena di lapangan secara mendalam melalui serangkaian wawancara dengan segenap key persons.

\section{Hasil dan Pembahasan}

Kabupaten Bantul dalam rangka memberikan pelayanan publik berbasis ICT, maka telah membangun sub domain dan fasilitas e-mail 182 alamat sampai tingkat desa. Hal ini untuk mendukung berhasilnya pelayanan publik di Kabupaten Bantul. Diantara sub domain yang dibangun antara lain :

1. http://www.bantulkab.go.id, situs ini dimanfaatkan untuk menyampaikan informasi yang terkait Profil Kabupaten Bantul, Penyelenggaraan Pemerintahan Kabupaten Bantul dari seluruh SKPD melalui subdomain. Layanan komunikasi pemerintah dengan masyarakat melalui buku tamu dan ide warga dengan 54 Sub domain.

2. http://www.bantulbiz.com, situs ini dimanfaatkan untuk menyampaikan informasi yang terkait Pelaku Bisnis terutama dari bisnis masyarakat di Kabupaten Bantul.

3. www.bantulcraft.go.id, situs ini dimanfaatkan untuk menyampaikan informasi yang terkait Industri Kerajinan warga dan masyarakat Bantul

4. perijinan.bantulkab.go.id, subdomain Perijinan online ini untuk menyampaikan informasi dan memfasilitasi masyarakat yang akan mencari informasi dan pelayanan perijinan.
5. Kewilayahan.bantulkab.go.id, subdomain Kewilayahan ini dapat memfasilitasi masyarakat dalam menentukan dan merencanakan tata ruang dan wilayah (advice planning).

6. potensiwisata.bantulkab.go.id, subdomain Sistem Potensi Wisata dan Kuliner menampilkan informasi Potensi Wisata dan segala Kuliner yang ada di Wilayah Kabupaten Bantul yang dilengkapi dengan peta digital atau WebGIS.

7. hukum.bantulkab.go.id, melalui situs ini ditampilkan Produk Hukum Pemerintah Kabupaten Bantul seperti Peraturan Daerah, Peraturan Bupati, Keputusan Bupati dan Instruksi Bupati .

8. lpse.bantulkab.go.id, merupakan sistem informasi yang memfasilitasi proses pengadaan barang dan jasa

9. Invesda.bantulkab.go.id Melalui situs ini ditampilkan Investasi di wilayah Pemerintah Kabupaten Bantul yang dapat disampaikan kepada masyarakat.

10. Shbj.bantulkab.go.id Sarana publikasi Standar harga barang dan Jasa sebagai upaya mewujudkan pemerintahan yang transparan dan akuntabel.

11. Warintek.bantulkab.go.id Merupakan situs Pemeritah Kabupaten Bantul yang menampilkan dan menyediakan informasi Teknologi sebagai sarana pembelajaran untuk meningkatkan pengetahuan dan kemampuan yang terkait Teknologi dan perkembangannya.

12. sistel.bantulkab.go.id Sistem telekomunikasi merupakan Sistem Informasi yang memberikan kemudahan dan efisiensi bagi masyarakat terkait dengan Permohonan pendirian menara telekomunikasi, disamping itu sebagai fasilitas bagi pemerntah untuk melaksanakan tugas pemantauan dan pengendalian menara telekomunikasi .

13. Intranet.bantulkab.go.id Sistem Intranet Kabupaten digunakan untuk mem- 
Tersedia Online di http://journal.unismuh.ac.id/index.php/otoritas

Otoritas : Jurnal Ilmu Pemerintahan, 6 (2), Oktober 2016, 123

berikan fasilitas dan kemudahan bagi SKPD pemerintah Kabupaten Bantul untuk menyimpan/backup data, tukar menukar data dan pemindaian perangkat lunak (download software/ master).

14. Simdalbangda.bantulkab.go.id Simdalbangda adalah Sistem Informasi manajemen Pengendalian Pembangunan Pemerintah Kabupaten Bantul, digunakan untuk menyimpan data, mengolah dan menginformasikan Proses dan pengendalian Pembangunan,

15. Simbada.bantulkab.go.id SIMBADA adalah sistem informasi Manajemen yang difungsikan untuk menyimpan, mengolah dan menginformasikan aset atau Barang Milik daerah Kabupaten Bantul.

16. Simkeuda.bantulkab.go.id Sistem Informasi Keuangan difungsikan untuk meyimpan, mengolah dan menampilkan informasi/pelaporan data anggaran, penatausahaan keuangan.

17. Sim ijin reklame Sistem informasi yang berfungsi untuk menyimpan, mengolah dan mengunformasikan/ pelaporan data permohonan ijin reklame.

18. Sim pengelolaan data pedagang pasar Melalui situs ini ditampilkan Produk Hukum Pemerintah Kabupaten Bantul seperti Peraturan Daerah, Peraturan Bupati, Keputusan Bupati dan Instruksi Bupati .

19. Sim bphtp (Biaya perolehan hak atas tanah dan bangunan) Melalui situs ini ditampilkan Produk Hukum Pemerintah Kabupaten Bantul seperti Peraturan Daerah, Peraturan Bupati, Keputusan Bupati dan Instruksi Bupati .

20. Sim pengelolaan penggajian pegawai kabupaten bantul Sistem informasi yang digunakan untuk menyimpan, mengolah dan menampilkan informasi/pelapran data gaji pegawai kabupaten Bantul.
21. Sim pengelolaan data sp2d Melalui situs ini ditampilkan Produk Hukum Pemerintah Kabupaten Bantul seperti Peraturan Daerah, Peraturan Bupati, Keputusan Bupati dan Instruksi Bupati .

22. Sistem informasi administrasi kependudukan Sistem Informasi Administrasi Kependudukan (SIAK) merupakan aplikasi dari Pusat yang sudah dimanfaatkan oleh Dinas Kependudukan dan catatan sipil untuk pelayanan administrasi kependuduk untuk masyarakat. SIAK ini menggunakan Infrastruktur Jaringan yang difasilitasi oleh Kantor PDT yang pada awalnya akan menggunakan Jaringan VPN dengan konskuensi yang sangat mahal

23. Sistem informasi pelaporan dan akuntansi Sistem Akuntasi digunakan untuk mengelola (penyimpanan, pengolahan dan menampilkan informasi) data Akuntasi dan pelaporan

24. Sistem informasi pemutakhiran data keluarga miskin Sistem informasi yang akan memfasilitasi pengelolaan (menyimpan, mengolah dan menampilkan infoemasi) dan pengambilan keputusan untuk penentuan Keluarga Miskin di Kabupaten Bantul .

25. Sistem pengendalian pembangunan daerah Sistem informasi ini difungsikan untuk entry data (menyimpan), mengolah dan menampilkan informasi yang terkait dengan proses pelaksanaan pekerjaan dan kegiatan pembangunan secara fisik dan keuangan.

26. Sistem informasi perencanaan pembangunan Sistem Informasi Perencanaan Pembangunan berguna untuk menyediakan fasilitas pengelolaan data dan informasi atas program dan kegiatan yang direncanakan dalam pembangunan dari basis kecamatan bahkan rencananya sampai basis desa.

27. E-audit (kerjasama BPK) Sistem yang

Copyright (C) 2016, Otoritas : Jurnal Ilmu Pemerintahan, p-ISSN: 2088-3706, e-ISSN: 2502-9320 
Tersedia Online di http://journal.unismuh.ac.id/index.php/otoritas

Otoritas : Jurnal Ilmu Pemerintahan, 6 (2), Oktober 2016, 124

diaktifkan oleh BPK dan Kabupaten Bantul sebagai salah satu Agen Konselor untuk melakukan proses audit penyelenggaraan keuangan di Pemerintah Kabupaten Bantul.

28. E-OFFICE Sistem e-Office akan memfasilitasi layanan persuratan dan disposisi dan pengarsipan sesuai dengan prosedur dan mekanisme yang berjalan (Peraturan Bupati Nomor 62tahun 2010 tentang Pedoman Tata naskah Dinas di Lingkungan Kabupaten Bantul).

29. Sistem Perencanaan Pembangunan Sistem Perencanaan Pembangunan digunakan untuk memfasilitasi pengolahan data perencanaan pembangunan Kabupaten Bantul

30. Sistem Penanggulangan kemiskinan Sistem Penanggulangan Kemiskinan digunakan untuk memfasilitasi pengolahan data Keluarga Miskin di Kabupaten Bantul

31. Sistem Pengendalian lingkungan Sistem Pengendalian Lingkungan digunakan untuk memfasilitasi pengolahan dokumen dan pengendalian lingkungan

32. Sistem Informasi Sarana Kesehatan (Peta Sebaran Fasilitas Layanan Kesehatan)

33. Sistem Informasi PATEN (Pelayanan Administrasi Terpadu Kecamatan)

Dari variabel yang diteliti maka perlu dilakukan uji validitas dan realibitas data, dari hasil uji Pearson dari 4 variabel yang diteliti maka diperoleh hasil sebagaimana dalam tabel 1 .

Dari hasil perhitungan menunjukkan signifikan pada tingkat 0,05 karena ketika dibandingkan dengan $r$ tabel sebesar 0,220, maka $r$ hitung lebih besar. Artinya variabel yang diteliti termasuk kategori yang valid atau layak dilakukan penelitian. Selanjutnya akan dipaparkan deskriptif statistik yang menggambarkan tentang jumlah responden dalam pengambilan data, sebaran nilai minimal, maximal dan nilai rata-rata, serta standar deviasi, yang secara rinci sebagaimana dalam tabel 2.

Dari tabel 2 nampak bahwa dari tabulasi dapat dijelaskan bahwa nilai minimal, nilai maksimal dan nilai rata-rata dari masing-masing variabel dan masingmasing lokasi penelitian, yang menunjukkan angka sebaran yang cukup antara satu responden dengan responden yang lain.

Untuk mengetahui hubungan antara variabel bebas dengan variabel terikat dapat digambarkan dalam tabel 3 .

Dari tabel 3 dijelaskan bahwa besar korelasi antara variabel penerapan sistem ICT dan pengaruhnya terhadap variabel pelayanan publik dengan di Kabupaten Bantul sebesar 0,18 atau $18 \%$.

Dibukanya sistem ICT telah mampu meningkatkan partisipasi warga dalam memberikan informasi dan keluhan kepada pemerintah daerah/ kota. Namun ada persoalan terkait dengan kecepatan respon birokrasi dalam menjawab keluhan dan tuntutan warga.

Dari penelitian menunjukkan hasil terkait dengan faktor-faktor yang mempengaruhi aplikasi ICT dan hubungannya dengan pelaksanaan pelayanan publik di Kabupaten Bantul.

Hasil pertama yang didapatkan adalah dalam skala tertentu ada hubungan antara visi dan kebijakan dengan pelayanan publik, Dari hasil analisis hubungan visi dan kebijakan terhadap pelayanan publik di Kabupaten Bantul sebesar 0,185 , ataui sebesar $18,5 \%$ dengan tingkat kepercayaan 95 5\%. dengan $\mathrm{F}$ tabel sebesar 0,220, sehingga hubungan signifikan. Hubungan visi dan kebijakan dengan pelayanan publik ini bisa dibuktikan dengan banyaknya kebijakan yang menjadi landasan pemberian pelayanan publik.

Faktor visi dan kebijakan atau regulasi daerah juga sangat menentukan atas keberhasilan pelaksanaan kebijakan ICT, jika regulasi itu secara konsisten dil- 
Tersedia Online di http://journal.unismuh.ac.id/index.php/otoritas

Otoritas : Jurnal Ilmu Pemerintahan, 6 (2), Oktober 2016, 125

Tabel 1. Uji Validitas dan Realibilitas (Hasil Tabulasi Data, 2016)

\begin{tabular}{|c|c|c|c|c|}
\hline Variabel & $\begin{array}{l}\text { Scale Mean if } \\
\text { Item Deleted }\end{array}$ & $\begin{array}{l}\text { Scale Variance } \\
\text { if Item Deleted }\end{array}$ & $\begin{array}{l}\text { Corrected Item } \\
\text {-Total asi Cor- } \\
\text { relation }\end{array}$ & $\begin{array}{l}\text { Cronbach's Al- } \\
\text { pha if item De- } \\
\text { leted }\end{array}$ \\
\hline Visi kebijakan & 117.3000 & 179.459 & .526 & .766 \\
\hline $\begin{array}{l}\text { Struktur } \\
\text { ganisasi }\end{array}$ & 119.5857 & 162.478 & .718 & .652 \\
\hline $\begin{array}{l}\text { Perubahan Bu- } \\
\text { daya Organ- }\end{array}$ & 122.4429 & 132.772 & .707 & .662 \\
\hline $\begin{array}{l}\text { isasi } \\
\text { Pembaharuan }\end{array}$ & 123.1234 & 231.023 & .614 & 725 \\
\hline ICT & 132.2857 & 235.946 & .486 & .778 \\
\hline $\begin{array}{l}\text { Pelayanan } \\
\text { Publik }\end{array}$ & & & & \\
\hline
\end{tabular}

Tabel 2. Deskripsi Statistik (Hasil Penelitian, 2016)

\begin{tabular}{lccccc}
\hline Variabel & $\mathrm{N}$ & Min & Max & Mean & $\begin{array}{c}\text { Standar } \\
\text { Deviasi }\end{array}$ \\
\cline { 2 - 6 } & 80 & 27 & 39 & 31,3250 & 2,53470 \\
\hline $\begin{array}{l}\text { Transformasi } \\
\text { birokrasi }\end{array}$ & 80 & 42 & 56 & 50,5025 & 3,54713 \\
\hline Visi dan kebijakan & 80 & 38 & 56 & 47,0500 & 2,92133 \\
\hline Struktur Organisasi & 80 & 43 & 55 & 43,6000 & 2,60282 \\
\hline $\begin{array}{l}\text { Perubahan } \\
\text { Orgaanisasi }\end{array}$ & 80 & 16 & 27 & 20,61 & 2,52523 \\
\hline Pembaharuan ICT & & & & & \\
\hline
\end{tabular}

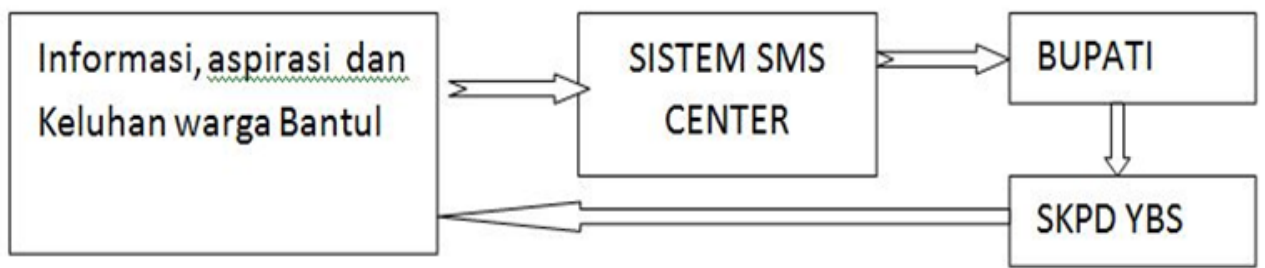

Gambar 1. Informasi Dan Sistem SMS Center (Hasil Penelitian, 2016) 
Tersedia Online di http://journal.unismuh.ac.id/index.php/otoritas

Otoritas : Jurnal Ilmu Pemerintahan, 6 (2), Oktober 2016, 126

Tabel 3. Hubungan Variabel Bebas Terhadap Terikat di Kab. Bantul (Hasil Tabulasi Data, 2016)

\begin{tabular}{|c|c|c|c|c|c|c|}
\hline & & Y & $\mathrm{X} 1$ & $\mathrm{X} 2$ & X3 & $\mathrm{X} 4$ \\
\hline \multirow[t]{5}{*}{ Pearson Correlation } & $\mathrm{Y}$ & 1.000 & -.185 & -.315 & -.057 & .18 \\
\hline & $\mathrm{X} 1$ & -.185 & 1.000 & .246 & -.135 & .142 \\
\hline & $\mathrm{X} 2$ & -.315 & .246 & 1.000 & .021 & -.025 \\
\hline & X3 & -.057 & -.135 & .021 & 1.000 & .015 \\
\hline & $\mathrm{X} 4$ & .018 & .142 & -.025 & .015 & 1.000 \\
\hline \multirow[t]{5}{*}{ Sig. (1-tailed) } & $\mathrm{Y}$ & . & .051 & .002 & .309 & .438 \\
\hline & $\mathrm{X} 1$ & .051 & . & .014 & .116 & .105 \\
\hline & $\mathrm{X} 2$ & .002 & .014 & . & .426 & .414 \\
\hline & X3 & .309 & .116 & .426 & . & .447 \\
\hline & $\mathrm{X} 4$ & .438 & .105 & .414 & .447 & \\
\hline \multirow[t]{5}{*}{$\mathrm{N}$} & $\mathrm{Y}$ & 80 & 80 & 80 & 80 & 80 \\
\hline & $\mathrm{X} 1$ & 80 & 80 & 80 & 80 & 80 \\
\hline & $\mathrm{X} 2$ & 80 & 80 & 80 & 80 & 80 \\
\hline & X3 & 80 & 80 & 80 & 80 & 80 \\
\hline & X4 & 80 & 80 & 80 & 80 & 0 \\
\hline
\end{tabular}

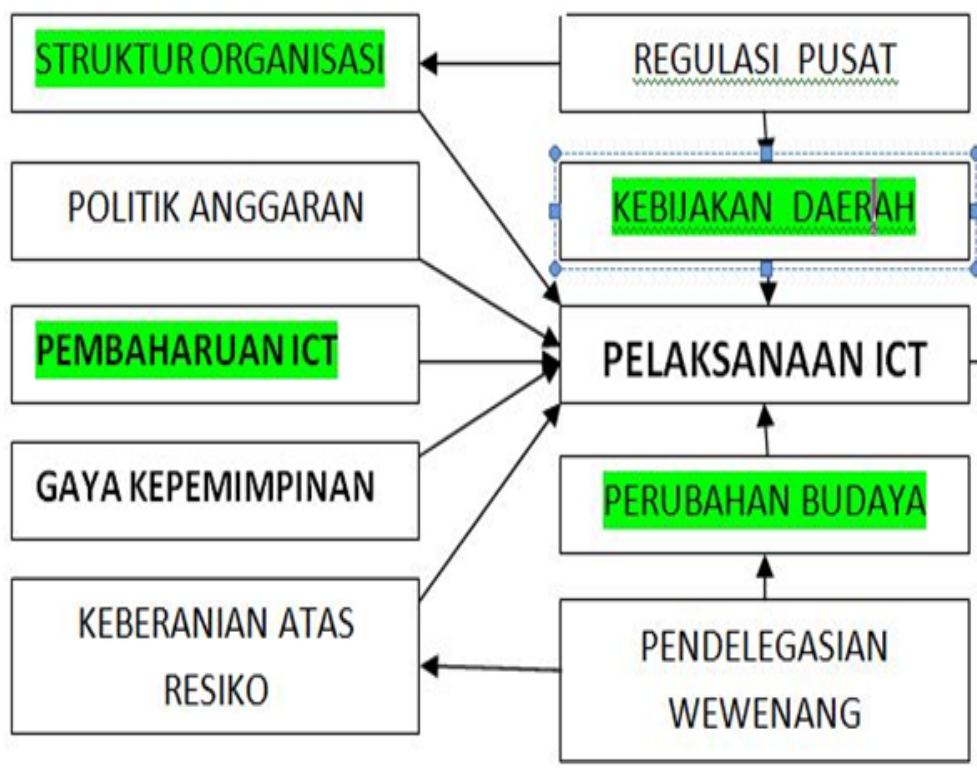

\section{TRANSFORMASI}

BIROKRASI

Gambar 2. Faktor-faktor yang mempengaruhi ICT (Hasil Penelitian, 2016) 
Tersedia Online di http://journal.unismuh.ac.id/index.php/otoritas

Otoritas : Jurnal Ilmu Pemerintahan, 6 (2), Oktober 2016, 127

Tabel 4. Faktor Pengaruh dan Implementasi ICT di Kab. Bantul (Hasil Olah Data, 2016)

\begin{tabular}{|l|l|l|}
\hline No & Faktor yang & \multicolumn{1}{|c|}{ Implementasi di Kabupaten Bantul } \\
\hline 1 & Kesiapan SDM Aparat & $\begin{array}{l}\text { Belum semua aparat siap untuk mengaplikasikan sistem } \\
\text { ICT, pada pegawai level kontrak jauh lebih menguasai } \\
\text { ICT }\end{array}$ \\
\hline 2 & $\begin{array}{l}\text { Komitmen Kepem- } \\
\text { impinan atas ICT }\end{array}$ & $\begin{array}{l}\text { Komitmen belum optimal, pelaksanaan ICT cenderung } \\
\text { normatif dan belum banyak terobosan-terobasan }\end{array}$ \\
\hline 3 & Relasi antar Aparat/ & $\begin{array}{l}\text { Hubungan aparat dan pimpinan cenderung hierarki } \\
\text { pimpinan }\end{array}$ \\
\hline 4 & Regulasi & $\begin{array}{l}\text { Kebijakan-kebijakan pendukung sudah cukup lengkap } \\
\text { lan komplit, namun konsistensinya dalam pelaksa- } \\
\text { naannya masih rendah, cenderung menunggu intruksi } \\
\text { atasan. }\end{array}$ \\
\hline 5 & Struktur Organisasi & $\begin{array}{l}\text { Lebih kuat karena dikelola oleh kantor PDT, kelem- } \\
\text { bagaan ICT belum diberi nama khusus seperti Kota Yog- } \\
\text { ya (UPIK), maka namanya SMS Center saja. }\end{array}$ \\
\hline
\end{tabular}

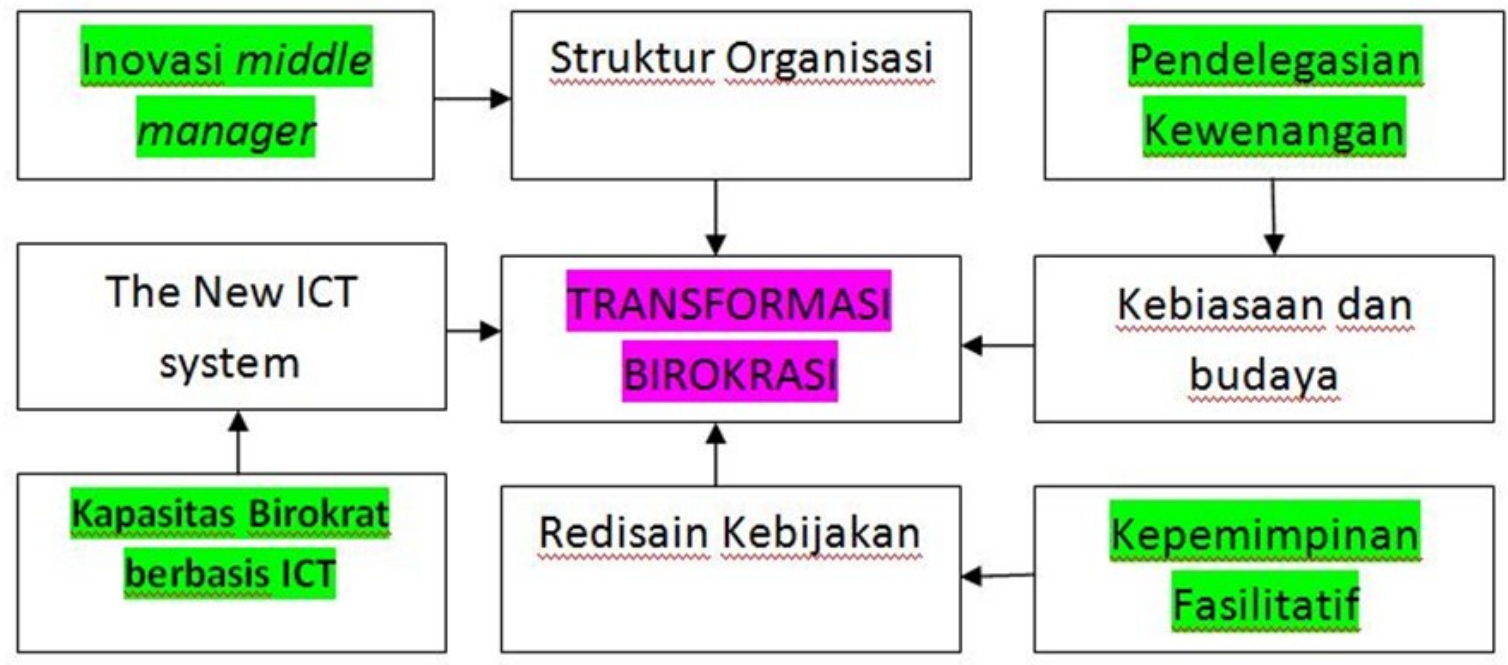

Gambar 3. Faktor yang Berpengaruh Pada Tranformasi Birokrasi (Hasil Penelitian, 2016) 
Tersedia Online di http://journal.unismuh.ac.id/index.php/otoritas

Otoritas : Jurnal Ilmu Pemerintahan, 6 (2), Oktober 2016, 128

aksanakan. Faktanya saat ini banyak regulasi-regulasi yang diciptakan untuk meningkatkan kualitas layanan publik, tetapi konsistensi dan komitmen pelaksanaan sangat rendah. Untuk itulah aspek konsistensi dalam pelayanan publik harus menjadi perhatian pucuk pimpinan organisasi.

Dalam hal ini secara regulasi sudah cukup lengkap, bahkan sampai petunjuk operasional prosedurnya sudah tersedia, namun implementasinya belum semua kebijakan ini bisa terlaksana, bahkan banyak aktivitas pelayanan pada masyarakat yang didasarkan pada perintah atasan. Untuk itulah pentinngya inovasi dan progresivitas Kepala SKPD untuk berinovasi dalam menjalankan dan mensikapi kebijakan, termasuk dalam pelaksanaan sistem ICT untuk mendukung pelayanan publik.

Hasil yang kedua adalah mengenai hubungan struktur organisasi dengan pelayanan publik, hasil analisis pengaruh struktur organisasi dengan pelayanan publik sebesar 0.315 , atau sebesar 31,5 \% di Kabupaten Bantul, dan signifikan ketika dibandingkan dengan $\mathrm{f}$ tabel pada angka 0,220 karena $F$ hitung lebih besar dibandingkan dengan $\mathrm{F}$ tabel.

Dalam konteks struktur organisasi di pemerintahan daerah, termasuk di kabupaten Bantul menunjukkan hubungan organisasi hierarki yang ketat, sehingga seorang aparat bawahan tidak mungkin bertindak tanpa komando pimpinan. Dalam pelaksanaan sistem ICT membutuhkan hubungan antar aparat bersifat horizontal. Di sisi lain aparat yang mempunyai kapasitas ICT tidak disertai dengan kewenangan tertentu, sehingga tidak bisa mengembangkan inovasi dalam merespon aspirasi warga daerah. Rata-rata di daerah penerima aspirasi dan keluhan warga oleh admin di masing-masing SKPD, selanjutnya petugas mem-print out dan melaporkan pada atasan, selanjutnya dirapatkan dan direspon oleh bidang terkait, sehingga terkesan penerimaan dan respon kepada warga menggunakan sistem manual atau tradisional, karena proses relasi antar aparat belum paperless.

Pimpinan SKPD yang seharusnya bisa mengakses langsung aspirasi warga berbasis ICT ini, tidak dilakukan melainkan menunggu laporan admin dalam bentuk print out. Dengan demikian lebih menekankan hubungan yang berbasis hierarki atau atas-bawah. Hal ini bertentangan dengan prinsip pelayanan berbasis ICT, dimana pendekatan relasi yang horizontal bukan hierarki atau vertikal. Dalam hal ini struktur SKPD cenderung mengikuti nomenklatur berdasarkan kebijakan pemerintah pusat. Untuk itu dalam rangka aplikasi sistem ICT di instansi dinas, maka dibutuhkan kepemimpinan SKPD yang fasilitatif dan terbuka terhadap sistem ICT tersebut. Dengan demikian kepemimpinan menengah (middle manager) dalam hal ini kepala SKPD akan menentukan efektif tidaknya pelaksanaan sistem ICT. Dalam kasus Pemerintah Kota Yogyakarta, misalnya dimana walikota (top manager) memberikan pelimpahan kewenangan untuk merespon secara cepat terhadap aspiratif dan tuntutan warga, sehingga kepala SKPD bisa langsung meresponnya. Sedangkan di Kabupaten Bantul pimpinan SKPD masih menunggu disposisi Bupati untuk merespon tuntutan warga berbasis ICT, sehingga respon birokrasi terkesan lamban.

Pentingnya adanya keberadaan untuk pendelegasian kewenangan top manager dalam konteks relasi dengan warga, dalam arti hal-hal yang bisa direspon secara cepat tidak perlu rapat, karena hal ini bisa diselesaikan dengan komunikasi elektronik misal dengan SMS, BBM, WA maupun dengan telepon. Seharusnya pimpinan SKPD sebagai middle manager tidak harus menunggu laporan admin, tetapi bisa akses langsung dimanapun, selanjutnya merespon sesuai perencanaan program tahunan SKPD, sehingga 
Tersedia Online di http://journal.unismuh.ac.id/index.php/otoritas

Otoritas : Jurnal Ilmu Pemerintahan, 6 (2), Oktober 2016, 129

keberadaan admin hanya bersifat administrasi saja. Hal ini bisa jika SDM aparat dan pimpinan mempunyai kapasitas bidang ICT, fakta di lapangan belum semua pimpinan SKPD mempunyai kapasitas tersebut. Dalam hal ini Pemerintaah Kota Yogyakarta mempunyai kesiapan dan kapasitas cukup memadai, karena dalam manajemen sumber daya diterapkan sistem semacam reward and punishment, dimana pegawai yang sudah menguasai sistem ICT akan dilibatkan dalam berbagai kepanitian dan tugas tambahan, sehingga setiap pegawai berlomba-lomba untuk meningkatkan kapasitas. Pada faktanya pemda Kabupaten Bantul, lebih berorientasi pada penyediaan hardware dan software-nya ketimbang menyiapkan sumber daya manusia yang memadai, sehingga tidak jarang justru perangkat ICT ini menjadi penghambat pelayanan daripada meningkatkan efektivitas dan efisiensi pelayanan pada masyarakat.

Hasil yang ketiga terkait dengan Hubungan perubahan budaya organisasi terhadap transformasi birokrasi di kabupaten Bantul menunjukkan pengaruh sebesar 0,057 atau sebesar $5,7 \%$, dan signifikan pada tingkat kepercayaan 0,05 , karena dibandingkan dengan $F$ tabel hasilnya lebih besar $f$ hitung.

Fakta di lapangan ditemukan masih ada pimpinan yang cenderung bersifat tradisional (patron-klein), sehingga perilakunya belum sesuai dengan IT mainded. Ada sebagian pimpinan SKPD di daerah yang belum familiar dengan kerja berbasis ICT, sehingga tidak menempatkan kebutuhan ICT pada posisi yang prioritas, seolah sistem ini hanya menjadi pelengkap di instansi saja. Hal ini nampak dalam penempatan sarana pendukung ICT yang belum proporsional, misalnya di SKPD tertentu ditempatkan di bilik belakang yang kecil dan kumuh. Hal lain yang substantif bahwa informasi dan keluhan warga lewat online dianggap hanya latah dan tidak perlu ditanggapi serius, mereka menganggap kalau warga serius ya mestinya datang ke kantor dan menyampaikan maksud dan masalahnya. (Wawancara Pejabat di SKPD Bantul, 510-2015). Dengan demikian belum semua pejabat struktural di lingkungan SKPD menganggap penting masukan dan aspirasi berbasis website, dengan kata lain belum semua mempunyai komitmen untuk mengembangkan sistem informasi berbasis website yang lebih praktis, efektif dan efisien atau belum ada perubahan budaya organisasi kearah ICT.

Dalam hal budaya kepemimpian patron-klien yang sangat kuat di Bantul ikut memberikan pengaruh warga dalam aplikasi pelayanan berbasis ICT. Pendekatan kepemimpinan, model ini lebih menempatkan hubungan hieraki yang sangat kuat, sementara pendekatan yang dibutuhkan dalam pelaksanaan sistem ICT adalah model relasi horizontal. Dengan demikian pelaksanaan sistem ICT cenderung termarginalkan relasi horizontal karena kuatnya pengaruh model kepemimpinan ini. Bahkan aparat bawahan tidak akan bergerak sekalipun aturannya ada, prosedurnya ada tanpa komando pimpinan. Sebagai misal ada keluhan warga kepada satpol PP tentang PKL yang berdagang di trotoar sehingga mengganggu pedestrian, dalam hal ini aturannya sangat jelas, namun belum tentu ditindak-lanjuti kalau belum ada perintah dari pimpinan. Ternyata pimpinan tidak memerintahkan satpol PP, karena PKL mendapat restu dari oknum anggota DPRD. Jadi faktor kepemimpinan patron klein dengan politisasi birokrasi sangat berpengaruh dalam pelaksanaan suatu kebijakan yang ditetapkan oleh pemerintah daerah.

Faktor lain di instansi pemerintah daerah khususnya di SKPD ada semacam pembusukan birokrasi (patologi birokrasi), sehingga dalam pelaksanaan tugas cenderung bernuansa politis. Ada fakta ditemukan bahwa dalam menindaklanjuti aspirasi warga, suatu SKPD menerima laporan warga tentang jalan 
Tersedia Online di http://journal.unismuh.ac.id/index.php/otoritas

Otoritas : Jurnal Ilmu Pemerintahan, 6 (2), Oktober 2016, 130

berlobang misalnya, dalam hal ini anggaran pemda ada, namun realisasinya tidak bisa secepat yang diharapkan warga, sehingga harus menunggu terlebih dahulu sementara waktu, baru ketika ada laporan korban kecelakaan dari akibat jalan berlobang baru diperbaiki (wawancara dengan Pejabat Struktural Bantul, Desember 1015). Demikian pula saat realisasi tuntutan warga untuk fogging demam berdarah juga realisasinya menunggu ada korban dulu, dengan demikian seolah birokrasi dalam merespon warga ada semacam vested interest tertentu. Hal ini juga tidak terlepas bahwa birokrasi yang tidak bekerja pada aspek teknokrat saja tetapi juga pada demensi politis. Hal ini dikaitkan dengan proses rekruitmen pimpinan SKPD yang sangat kental dengan nuansa politis.

Dengan dilaksanakan sistem ICT ada perubahan budaya kerja di Kabupaten Bantul, maka manajemen pemerintah yang lebih fleksibel, aparat bergerak sesuai regulasi, dan selalu beradaptasi dengan berbagai perubahan kebutuhan para pelanggan, baik yang berasal dari kalangan birokrat sendiri (internal) maupun dari luar lembaga pemerintahan (eksternal). Kunci sukses manajemen dengan gaya fleksibel ini terletak pada kemampuan para birokrat bekerja secara tim (teamwork). Pendistribusian informasi ke setiap SKPD dan unit kerja di kota Yogyakarta oleh sekretariat UPIK dilakukan secara paperless, dimana sedapat mungkin penggunaan kertas dikurangi, penyampaian pesan langsung melalui SMS gateway, email dan aplikasi chatting internal membuat biaya komunikasi menjadi sangat murah dan cepat (Wawancara dengan Aris di TIT, Januari 2016). Beberapa area perubahan dalam reformasi birokrasi ini dicapai tidak dalam waktu singkat, perlu waktu sembilan tahun. Perubahan memerlukan waktu dan kerjasama dari para pemangku kepentingan Pemerintah Kota, dalam gambar 1 .

Sedangkan kasus untuk Kabupaten
Bantul, perubahan kultur organisasi dan birokrasi cenderung berjalan lamban, karena sebagian besar aparat daerah cenderung bergerak karena komando pimpinan. Pada hal sudah ada berbagai regulasi dan standar operasional prosedur yang menjadi dasar aparat bertindak. Faktanya aparat tidak mempunyai sikap kemandirian dan inovasi dalam pelayanan, mereka cenderung menunggu perintah pimpinan. Dalam banyak hal diciptakan harmonisasi organisasi, sehingga dinamika hubungan pimpinan dengan bawahan tidak terjadi, sehingga sulit mengaharapkan ada perubahan dalam sistem seperti ini, karena ketergantungan pada pimpinan yang begitu tinggi.

Dari gambar 1 menunjukkan bahwa informasi dan keluhan yang masuk ke sistem SMS Center, selanjutnya disampaikan Bupati untuk diteruskan ke SKPD, dari SKPD dilakukan koordinasi untuk ditugaskan kepada kepala seksi terkait dengan aspirasi warga.

Hasil yang keempat didapati bahwa hubungan pembaharuan sistem ICT dengan transformasi birokrasi di Kabupaten Bantul sebesar 0,18 atau $18 \%$. Hal ini menunjukkan bahwa pelaksanaan ICT dalam penyelenggaraan pemerintahan di Kabupaten Bantul belum optimal.

Selanjutnya dapat dipetakan kondisi riel di Kabupaten Bantul terkait dengan berbagai faktor yang mempengaruhi pelaksanaan sistem ICT sebagaimana tertera dalam tabel 4.

Penerapan ICT bisa mendukung pelayanan masyarakat secara efektif dan efisien jika didukung dengan kapasitas sumber daya pegawai, persoalannya kapasitas birokrasi dalam merespon aspirasi warga, hal inilah yang menjadi fokus dari penelitian ini. Dalam hal ini kapasitas aparat pegawai dipengaruhi visi dan kebijakan organisasi, struktur organisasi dan perubahan budaya organisasi, serta pembaharuan ICT, sehingga pelayanan publik terjadi jika keempat pilar tersebut cukup mendukung peningkatan 
kapasitas sumber daya aparat daerah. Hasil penelitian di kabupaten Bantul, bahwa pilar visi dan kebijakan, struktur organisasi, dan budaya organisasi, serta pembaharuan ICT belum berubah secara struktural, sehingga pelaksanaan sistem ICT belum mendukung secara optimal terhadap pelayanan publik.

Jika pemda ingin melaksanakan sistem ICT dalam penyelenggaraan pemerintahan yang perlu disiapkan adalah kesiapan kapasitas sumber daya, bukan perangkat keras IT yang diutamakan, karena biasanya pemda lebih memprioritaskan menyiapkan perangkat keras, sedangkan sistem dan struktur birokrasi belum disiapkan. Dalam rangka penguatan kapasitas birokrasi, maka perlu dilakukan perubahan dari sisi visi dan kebijakan yang pro ICT, struktur organisasi yang kondusif bagi pelaksanaan ICT dan perubahan kultur birokrasi ke ICT minded.

Pelaksanaan sistem ICT membawa konsekuensi perubahan struktur organisasi harus sesuai dengan kebutuhan sistem, seperti lebih menekankan hubungan organisasi yang bersifat horizontal. Dalam struktur organisasi di SKPD berdasarkan nomenklatur yang diatur Peraturan Pemerintah relasi antara aparat dan pimpinan lebih bersifat vertikal, sehingga pelaksanaan sistem ICT yang lebih mengedepankan struktur hubungan horizontal berhadapan dengan struktur yang hierarkis. Akibatnya pelaksanaan sistem ICT terkendala oleh struktur organisasi pemda yang hierarki, dalam hal ini SKPD sebagai pelaksana kebijakan bupati atau walikota mengalami kebuntuan. Hal ini berimplikasi pada peran inovatif pimpinan SKPD (midle manager) untuk mengambil inisiatif dan prakarsa untuk melaksanakan sistem ICT secara konsisten. Artinya pelaksanaan sistem ICT akan bisa berjalan di pemda jika ada peran inovasi dari pimpinan SKPD atau kepala dinas, seperti dalam kasus Kabupaten Bantul dimana pimpinan SKPD diberi mandat dan kewenangan dari bupati langsung mengambil peran untuk mengakses langsung aspirasi warga kepada SKPD. Faktor -faktor yang turut berperan efektivitas penerapan ICT dalam mendukung transformasi birokrasi dalam pelayanan publik sebagaimana tergambarkan dalam gambar 2 .

Dengan kondisi sumber daya pegawai sudah terdapat perubahan budaya organisasi terhadap sistem ICT, maka pelaksanaan sistem ICT akan semakin optimal, dengan demikian perubahan kultur birokrasi akan mempengaruhi efektivitas sistem ICT. Fakta di lapangan menunjukkan bahwa perubahan budaya organisasi ke arah budaya ICT, sebagian besar SKPD sebagai implementator sistem ICT belum ada perubahan struktural ke arah budaya ICT, dengan demikian belum terjadi perubahan secara signifikan seperti kasus Kabupaten Bantul. Hal ini nampak pelaksanaan ICT di dinas-dinas yang masih ditempatkan sebagai ICT pelengkap saja, buktinya ICT diserahkan pengelolaannya oleh staf admin tanpa ada kewenangan sama sekali kecuali menerima pesan dan melaporkan pada atasan. Hasil penelitian ditemukan bekerjanya transformasi birokrasi di Kabupaten Bantul ditentukan oleh faktor-faktor lain sebagaimana tertera gambar 3.

Dari gambar dapat dijelaskan bahwa ditemukan menemukan bahwa transformasi birokrasi berbasis ICT ini ditentukan oleh 4 faktor yakni redesain visi dan kebijakan, struktur organisasi, kebiasaan dan budaya birokrasi, dan sistem ICT yang diperbaharui. Namun setelah temuan ini dijadikan acuan untuk mengetahui transformasi birokrasi dalam pelayanan publik di Kabupaten Bantul, ternyata hasilnya kurang signifikan karena hubungannya di Bantul sebesar $18 \%$. Lambannya perkembangan pelaksanaan sistem ICT dikarenakan masih banyaknya factor penghambat ICT. Untuk itu ditemukan faktor lain yang menentukan dan mendukung ICT di Kabupaten Bantul 
Tersedia Online di http://journal.unismuh.ac.id/index.php/otoritas

Otoritas : Jurnal Ilmu Pemerintahan, 6 (2), Oktober 2016, 132

ada 4 faktor tersebut yakni,

1. Inovasi middle manager atau dalam hal ini pimpinan SKPD harus mampu berdeskresi dan inovasi dalam melaksanakan sistem ICT, karena struktur organisasi secara nomenklatur sangat hierarkis, sehingga tidak mendukung pelaksanaan sistem ICT. Dengan faktor inovasi pimpinan menengah tersebut akan bisa menggerakan birokrasi di level SKPD untuk lebih responsive dalam menerima informasi warga berbasis ICT.

2. Pendelegasian kewenangan; masih kuatnya budaya patronase di pemerintahan daerah menyebabkan ketergantungan pada pimpinan, sehingga sulit untuk bisa menerima perubahan budaya ICT. Untuk itu dibutuhkan pendelegasian kewenangan dari pimpinan, sehingga masingmasing pejabat struktural berani mengambil kebijakan dan inisiatif dalam 'merespon warga berbasis ICT secara cepat dan tepat, tanpa harus menunggu komando pimpinan.

3. Kepemimpinan Fasilitatif; model kepemimpinan ini diperlukan untuk mengatasi masalah sikap kaku terhadap regulasi yang ada. Sebagaian besar birokrasi daerah selalu menempatkan hukum sebagai tujuan, akibatnya tindakan mereka sangat kaku dan statis, serta lamban karena takut resiko atas kebijakan tersebut. Dalam hal ini dibutuhkan kepemimpinan fasilitatif, dimana pejabat struktural daerah berani mengambil resiko untuk bertindak secara cepat untuk membela bawahan dan warga yang dilayaninya,

4. Kapasitas birokrasi berbasis ICT; jika di Negara-negara maju kebaruan sistem teknologi merupakan kebutuhan birokrasi, sehingga konsekuensinya kapasitas birokrasi bisa langsung menyesuaikan. Bagi Negara berkembang, termasuk di daerah-daerah, adanya sistem teknologi yang baru justru menjadi rintangan karena kapasitas birokrasi yang tidak mendukung. Untuk itu faktor peningkatan kapasitas birokrasi akan mempengaruhi dan mempercepat penerimaan pembaharuan teknologi, sehingga bisa mempercepat pelayanan publik berbasis ICT.

Jika Kabupaten Bantul ingin melaksanakan sistem ICT dalam penyelenggaraan pelayanan publik yang perlu disiapkan adalah kesiapan kapasitas sumber daya, bukan perangkat keras IT yang diutamakan, karena biasanya pemda lebih memprioritaskan menyiapkan perangkat keras, sedangkan sistem dan struktur birokrasi belum disiapkan. Dalam rangka penguatan kapasitas birokrasi, maka perlu dilakukan perubahan dari sisi visi dan kebijakan yang pro ICT, struktur organisasi yang kondusif bagi pelaksanaan ICT dan perubahan kultur birokrasi ke ICT minded.

Rendahnya transformasi birokrasi berbasis ICT, maka perlu dibangun birokrasi virtual yakni suatu sistem birokrasi baru yang didalamnya sudah mengalami perubahan mindset kearah ICT, dimana secara struktur organisasi sudah relevan kebutuhan operasionalisasi ICT, birokrasi dengan perubahan kultur birokrasi, serta produk kebijakan yang bisa menggerakkan dan mendukung aplikasi ICT dalam menjalankan pelayanan publik. Dalam kasus penerapan OPEN (Online Procedures Enhanncement for Civil Application) sebagai sarana anti korupsi di Seoul Korea Selatan (Seong Cheol Kim et.al, 2008). Dengan penedekatan institusional (regulatory/coersive, Cognitive/mimeic and normative), terbukti bahwa OPEN dari demensi regulasi efektif mencegah korupsi dengan didukung kepemimpinan yang kuat. Artinya faktor kepemimpinan lokal akan menentukan keberhasilan pelaksanaan sistem ICT.

Dalam tataran implementasi konsep birokrasi virtual menghadapi faktor 
Tersedia Online di http://journal.unismuh.ac.id/index.php/otoritas

Otoritas : Jurnal Ilmu Pemerintahan, 6 (2), Oktober 2016, 133

eksternal, seperti struktur organisasi diatur oleh peraturan pemerintah pusat, sehingga secara nomenklatur sudah ditentukan struktur pemda yang diharuskan dengan segala tupoksinya. Oleh karena itu perlu alternatif kebijakan inovatif terkait dengan peraturan pemerintah yang mengatur struktur organisasi yang relevan. Hal ini mungkin karena penerapan sistem ICT dalam pemerintahan ini dilindungi oleh Undang - undang Nomor 11 tahun 2008 tentang Informasi dan Transaksi Elektronik (ITE) dan Undang undang Nomor 14 Tahun 2008 Tentang Keterbukaan Informasi Publik, sehingga perlu disinkronkan antara keduanya. Sedangkan di tataran lokal pemerintahan daerah dengan segala otonominya bisa berkreasi dan berinovasi terkait dengan aplikasi sistem ICT ini bisa mengembangkan semacam struktur taskforce di masing-masing SKPD tanpa harus menghilangkan nomenklatur organisasi pemda yang diatur oleh peraturan pemerintah tersebut.

Hasilnya dapat disimpulkan bahwa Bupati (top manger) mencetuskan visi dan kebijakan terkait dengan penerapan sistem ICT dalam penyelenggaraan pemerintahan daerah, baik itu dalam pelayanan publik maupun saluran informasi dan keluhan warga pada pemerintah daerah. Selanjutnya pimpinan SKPD / Kepala Dinas (middle manager) sebagai pelaksanan kebijakan sistem ICT harus mempunyai inovasi dan prakarsa untuk mengkondisikan pelaksanaan sistem ICT berjalan optimal dengan mendelagasikan pada pimpinan operasional seperti Kepala Seksi untuk menjalankan kebijakan pimpinan SKPD, dalam hal ini merespon dan menindak-lanjuti aspirasi dan keluhan warga, Dengan demikian faktor penentu suskses tidaknya pelaksanan ICT pemda adalah pimpinan SKPD (middle manager) dengan berbagai inovasinya, karena sistem ICT terhambat struktur organisasi yang hierarkis.

Untuk itu diperlukan perubahan kultur organisasi dengan strategi pendelegasian kewenangan kepada bawahan untuk bisa merespon pesan yang masuk. Dengan demikian tidak ada lagi ketergantungan aparat terhadap pimpinan, sehingga terjadi pelembagaan peran dengan dukungan sistem ICT. Artinya dalam menjalankan peran aparatur sudah mempunyai kapasitas sistem ICT yang memadai, sehingga budaya ICT bisa berjalan.

Dengan demikian pelaksanaan ICT di Kabupaten Bantul yang sudah berjalan puluhan tahun belum mampu mendorong transformasi birokrasi dalam pelayanan publik. Artinya pelaksanaan ICT baik di Bantul masih dipengaruhi berbagai faktor seperti diuraikan diantaranya : pelaksanaan regulasi, budaya birokrasi, kepemimpinan, keberanian pegawai mengambil resiko dan politik anggaran daerah. Dengan kata lain pelaksanaan sistem ICT belum melembaga atau membudaya di kalangan birokrasi.

\section{Kesimpulan}

Dari analisis variabel melalui persepsi responden terhadap indikator variabel yang diteliti di Kabupaten Bantul sebagian besar responden berpendapat bahwa dari sisi regulasi, standar operasional dan sarana pendukung sudah cukup lengkap, namun dalam pelaksanaannya belum secara optimal, karena sumber daya belum cukup memadai dan kepemimpinan budaya patron klien kuat, sehingga inovasi pimpinan SKPD sangat rendah. Dengan demikian implementasi sistem ICT belum mampu mendukung transformasi birokrasi secara cepat dan memadai. Berdasarkan hasil analisis SPSS bisa diketahui hubungan antar variabel di Kabupaten Bantul bahwa Pengaruh pelaksanaan ICT terhadap transformasi birokrasi dalam pelayanan publik dalam kasus di Bantul sebesar $18 \%$ saja. Dengan demikian perkembangan transformasi birokrasi berbasis ICT berjalan lamban. Untuk Kabupaten Bantul penerapan ICT belum banyak mendorong terjadinya 
Tersedia Online di http://journal.unismuh.ac.id/index.php/otoritas

Otoritas : Jurnal Ilmu Pemerintahan, 6 (2), Oktober 2016, 134

transformasi birokrasi dalam pelayanan publik.

Dari hasil wawancara segenap pejabat struktural juga menunjukkan bahwa responsivitas birokrasi di Kabupaten Bantul belum optimal karena terkendala faktor struktur organisasi SKPD yang belum mendukung pelaksanaan sistem web karena ketatnya hubungan hierarki antara aparata dan pimpinan, sehingga respon birokrat masih lamban. Faktor kultur juga masih dominan patron-klien dan kurang ada delegasi kewenangan, sehingga pimpinan SKPD kurang inovatif dalam melaksanakan sistem web, cenderung menunggu perintah atasan dalam merespon aspirasi warga.

\section{Ucapan Terima Kasih}

Terima kasih kami sampaikan kepada Pimpinan STPMD “APMD” Yogyakarta, rekan sejawat pada Program S1 dan s2 Ilmu Pemerintahan, dan teman-teman yang memberi dukungan penuh pada proses penyelesaian artikel ini.

\section{Daftar Pustaka}

Dwiyanto, Agus,et,al (2002). Reformasi Birokrasi Publik di Indonesia. Yogyakarta: PPSK-UGM

Mustapa, Z. (2011). Reformasi Birokrasi Melalui E-Governance: Peluang atau Tantangan Dalam Pelayanan Publik?. OTORITAS: Jurnal Ilmu Pemerintahan, 1(2), 146-155.
Habibullah, A. (2010). Kajian Pemanfaatan dan Pengembangan EGovernment. Jurnal Ilmu Administrasi Negara, Fisip, Universitas Jember.

Sosiawan, E. A. (2015, June). Tantangan dan Hambatan dalam implementasi E-Government di Indonesia. In Seminar Nasional Informatika (SEMNASIF) (Vol. 1, No. 5).

Scott, W. Richard. 2001. Institutions and Organizations. Thousand Oaks, CA: Sage

Weerakkody, Vishanth, Marijn Janssen, Yogesh K. Dwivedi, 2011. Transformational change and business process reengineering (BPR): Lessons fromthe British and Dutch public sector, Government Information Quarterly 28 Journal. 